\title{
Michael Schwarze, Generische Wahrheit - Höfischer Polylog im Werk Jean Froissarts
}

\section{G. Matteo Roccati}

\section{Q OpenEdition}

10 Journals

\section{Édition électronique}

URL : http://journals.openedition.org/studifrancesi/34312

DOI : 10.4000/studifrancesi.34312

ISSN : 2421-5856

Éditeur

Rosenberg \& Sellier

\section{Édition imprimée}

Date de publication : 1 novembre 2005

Pagination : $389-390$

ISSN : 0039-2944

\section{Référence électronique}

G. Matteo Roccati, « Michael Schwarze, Generische Wahrheit - Höfischer Polylog im Werk Jean

Froissarts », Studi Francesi [En ligne], 146 (XLIX | II) | 2005, mis en ligne le 30 novembre 2015, consulté le 20 avril 2021. URL : http://journals.openedition.org/studifrancesi/34312 ; DOI : https://doi.org/ 10.4000/studifrancesi.34312

Ce document a été généré automatiquement le 20 avril 2021.

\section{(c)}

Studi Francesi è distribuita con Licenza Creative Commons Attribuzione - Non commerciale - Non opere derivate 4.0 Internazionale. 


\title{
Michael Schwarze, Generische Wahrheit - Höfischer Polylog im Werk Jean Froissarts
}

\author{
G. Matteo Roccati
}

\section{RÉFÉRENCE}

Michael SCHWARZE, Generische Wahrheit - Höfischer Polylog im Werk Jean Froissarts, Stuttgart, Franz Steiner Verlag (“Text und Context", 19), 2003, pp. 342.

1 Le volume est une bonne introduction à l'œuvre de Froissart, à travers l'étude de trois genres que ce dernier pratique: le dit allégorique, le roman arthurien, l'historiographie en prose. Les trois genres sont saisis comme l'expression, dans des formes différentes, d'une cohérence fondamentale, d'un système de valeurs morales, chevaleresque et courtois, désigné par le concept de curialitas. La première partie de l'ouvrage est consacrée aux dits, dont sont présentées les «dominantes» (thématique, forme d'écriture) et dont sont étudiés plus particulièrement le Paradis d'amour, l'Espinette amoureuse, le Joli buisson de Jonece et la Prison amoureuse. Les deux autres parties traitent du Meliador et des Chroniques. De ces dernières sont présentés: le rapport à la tradition de l'historiographie française en prose, le projet didactique et moral, sa réalisation narrative (interventions du narrateur, exempla et construction biographique du récit), la dimension esthétique, les «brèches» dans le discours chevaleresque sur l'histoire. La bibliographie termine le volume. 